\title{
NEGOTIATING MISSION: A CANADIAN STANCE
}

\author{
Marilyn J. Legge
}

Marilyn J. Legge is associate professor of Christian ethics at Emmanuel College, Victoria

University, Toronto, Canada. $\bullet$

\begin{abstract}
Introduction
Whoever you are, no matter how lonely,

the world offers itself to your imagination,

calls to you like the wild geese, harsh and exciting

over and over announcing your place

in the family of things. ${ }^{2}$
\end{abstract}

Mission is, quite simply, the participation of Christians in the liberating mission of 'Jesus ... wagering on a future that verifiable experience seems to belie. It is the good news of God's love, incarnated in the witness of a community for the sake of the world. ${ }^{1}$

Mission is the church's agenda, its raison d'être. Yet, what should mission be and do in the world of the 21st century? Like the church today, I am both fated and free, formed as both colonizing and colonized. I am shaped by missionary community and a white Canadian academic woman's privilege and constraints. ${ }^{3}$ There are many ways in which to frame the future of mission for this century. In this paper I will take one focus and assert that God's mission for the sake of the beloved world includes healing ourselves with the solidarity of others, and that justice/ love is the single standard for diverse discourses of mission. I frame mission in this way to explore how mission can be rethought as the relation between a particular understanding of church (as shaped by context and social location) and a particular understanding of the world, where both are governed by norms of justice/ right relations. I will begin with a snapshot of the Canadian context of ministry and mission, which will include something about my own denomination, the United Church of Canada. Secondly, I want to problematize mission through the case of

\footnotetext{
${ }^{1}$ David Bosch, Transforming Mission: Paradigm Shifts in Theology of Mission, Maryknoll, NY, Orbis Books, 1991; tenth printing, 1996, p. 519.

${ }_{2}^{2}$ Mary Oliver, "Wild Geese", Dream Work, NY, Atlantic Monthly Press, 1986, p. 14.

${ }^{3}$ See, for example, Dorothee Sölle, Thinking About God, Valley Forge, Pa, Trinity Press International, 1990, and Sharon Ringe, "A Place at the Table", in R.S. Sugirtharajah, The Postcolonial Bible, Sheffield Academic Press, 1998, pp. 136-151.
} 
Canadian churches confronting the legacy of their complicity in the cultural genocide of Aboriginal peoples, to indicate how "right" and "relations" connect when justice is construed as healing transformation. Lastly I will reframe mission as practices of solidarity that enhance justice/ love or right relation. ${ }^{4}$

\section{Canadian context of mission: Crisis}

What shapes the Canadian context and its diverse population of some 30 million people? Canada is a colonized and colonizing nation in the shadow of the American empire and the profound shifts in late 20th-century capitalism, especially globalization. Ursula Franklin assesses globalization as "a war against people." 5 As a nation, Canada faces major debt and structural adjustment pro grammes, with foreign loans accounting for forty percent of our national debt. Traditional economies based on fishery and renewable resources have collapsed. The so-called restructuring of the Canadian economy means that many face the bankruptcy of family farms, the weakening of the food industry and health care systems, and the loss of many thousands of jobs as industries move to the southern United States, Mexico and other areas of the world. We have major federal and provincial cutbacks to health, education and social programmes. More and more people rely on food banks. Those who are most vulnerable to HIV/AIDS in Canada, as in Africa, are women, especially those facing homelessness, unemployment, prostitution and domestic abuse. ${ }^{6}$ Violence against women remains a national horror. Many youth, even those with university education, are unlikely to have long-term jobs during the course of their lifetimes. Radical social theorists say that Canada increasingly bears the marks of a two-thirds world country, with a growing underclass and a more powerful elite. In short, with the global organization of the economy, Canadians especially experience both the demise of traditional church and community life as well as an unprecedented religious and cultural pluralism. On the one hand, fundamentalist Christians reassert the old notion of "mission as bringing the truth for civilizing alien cultures". On the other hand, old patterns of ecclesial domination - Christendom-style - are seen as a source of despair, and as colluding with newer forms of globalization that eviscerate persons, communities and the earth.7 This context requires us to re-examine our mission and thus what it means to be church.

The strength of my denomination, the United Church of Canada (UCC), is its long and faith ful history of commitment to the common good. It was established as a "union" church in 1925 by Methodists, Presbyterians and Congregationalists to share the gospel for the whole person and thus the social order. The UCC has a reputation as a progressive and prophetic

${ }^{4}$ For insight and encouragement as I prepared this paper I especially thank Betsy Anderson, Liz Bounds, Pamela Brubaker, Michael Bourgeois, Charles Fensham and Garth Legge.

5 Ursula M. Franklin, The Real World of Technology, Revised 1990, Massey Lectures, Toronto, Anansi, 1999.

${ }^{6}$ June Larkin, "Women, Poverty, and HIV infection", in Canadian Woman Studies, Fall 2000, vol. 20. no.3, p. 137.

${ }^{7}$ See Walter Brueggemann, "Missional Questions in A Fresh Context", in Hope for the World: Mission in a Global Context, Walter Brueggemann, ed., Louisville, Westminster John Knox Press, 2001, pp. 7-8. 
presence through its outspoken stances against exclusionary practices by church and society; this includes criticism of economic, racial, gender, sexual, ethnic and ecological injustice. Today, under conditions known as postmodernity, mainline churches have been disestablished from a Christendom position and are reeling with despair and confusion. Today, Canadian churches seek to be a community of faith that seeks earnestly and passionately to know and live what it believes. As D ouglas Hall poignantly asks,

What would it mean for the church to "carry on a mission to its world that is neither, on the one hand, the imposition upon its culture of extraordinary and arcane claims nor, on the other hand, a slightly pious, stained-glass version of the going values and pursuits of the dominant ethos?"8

At stake is an ethics of right relation that takes seriously this crisis of the postmodern globalized era and the churches' role in it.

Negotiating mission for the 21st century starts by giving attention to the massive suffering that exists, as well as the yearning for healing, justice and mutual relationship. It also seeks to name sources of pain and oppression, shows how healing, transformation and reconciliation are connected, is diversified amidst multiple communities of others, is accountable to those who are marginalized, and persistently resists violence in longing for justice/ love, peace and abundant life for all. ${ }^{9}$ Justice/ love is understood as "mutual respect and care and a fair sharing of power"; it is an intimate co -mingling of our longing for personal well-being in our bodies and right relatedness with others throughout the social order.10 I am not suggesting that we replace one discourse - mission or evangelism - with another of justice/ love. Instead, I will assert that God's mission for the sake of the beloved world includes healing ourselves with the solidarity of others, and that justice/ love is the single standard for diverse discourses of mission. Given this norm, it makes sense that Christians tuned to mission as negotiating justice/ love in all our relationships are moving into a more polycentric oik oumene of whole-earth community. ${ }^{11}$ How might Canadian churches recycle themselves into "a place in the family of things" so that mission resists "civilizing" and "colonizing", and at the same time finds energy and vision to embody justice/ love? One example of the salience of the themes I am pursuing here is the historical legacy of the churches' mission with Aboriginal peoples through residential schools in Canada.

${ }^{8} \mathrm{I}$ am especially indebted here to Douglas J ohn Hall, "The Future of the Church: Implications for Mission and Ministry", address to Emmanuel College, 15 May 2003. See also, for example, his The End of Christendomand the Future of the Churches, Valley Forge, Pa, Trinity Press International, 1997.

${ }^{9}$ See, for example, Chris Lind and Terry Brown, eds, Justice as Mission: An Agenda for the Church, Burlington, ON, Trinity Press, 1985; Marilyn Legge, The Grace ofDifference, Atlanta, GA, Scholars' Press, 1992; Phyllis Airhart et al, Doing Ethics in a Pluralist World, Waterloo, ON, Wilfred Laurier University Press, 2001; Loraine MacKenzie Shepherd, ed., Story After Story: Canadians Bend Bound Theology, Winnipeg, On Edge Publishing, 2003.

${ }^{10}$ See Marvin Ellison, Same-Sex Marriage? A Christian Ethical Analysis, Pilgrim Press, forthcoming, p. 144, andErotic Justice: A Liberating Ethic of Sexuality, Louisville, Westminster J ohn Knox Press, 1996.

${ }^{11} \mathrm{~S}$ ee, for example, Kwok Pui-lan, "Ecology and the Recycling of Christianity", in Hallman, ed., Ecotheology: Voices from South and North, Geneva, WCC, 1994; Larry Rasmussen, Earth Community, Earth Ethics, Maryknoll, NY, Orbis Books, 1996; and the United Church of Canada, Mending the World: An Ecumenical Vision for Healing and Reconciliation, 1997. 


\section{Problematizing mission: Presumed innocence, Canadian churches and Aboriginal people}

Evangelism is simply the sharing of the good news of God who is in Jesus Christ. One mission strategy has taken "the development of peoples" model which has, ironically, often resulted in further marginalization and exploitation of the poorest. ${ }^{12}$ Christianity has been an essential part of global imperial social ordering, regularly and morally legitimating the mechanisms of controlling markets and raw materials to exploit the colonies and their populations. "One of the cultural sins of First World Christians is the persistent assumption that G od's truth exists in some exclusive way in First World society, and that it is therefore the responsibility of those Christians to spread this truth to those less fortunate (namely peoples of the third world)." 13 The painful legacy of the cultural genocide of Aboriginal peoples is one that Canada is just now beginning to sort out; churches are also trying to learn to live and pray differently. I approach this issue as a fourth-generation Canadian of Scottish, Irish, and English ancestry, and with an abiding concern for women's diverse voices, moral agency, and analyses of justicemaking, i.e., of seeking right relations. ${ }^{14}$

Certainly,Canada is both a colonized and colonizing nation.15 It is an ex-colony of Britain and a satellite of the United States. Canada also has a long history of colonization and, in particular, of the political subjugation and cultural genocide of Native peoples. Christian complicity in the cultural genocide of Aboriginal peoples is being recognized today as religious institutions are discovering that this damage is not the result of benign neglect; indeed, the creation of inferior "others" has been and continues to be rooted in and made acceptable, even mandated, as "God's will". What is known as "the residential schools experience" bears serious lessons for churches

${ }^{12}$ For a handy introduction, see The No-Nonsense Guide to International Development, Toronto, Between the Lines and New Internationalist Publications, 2002. See also, for example, Kriemild Saunders, ed., Feminist Post-Development Thought Re-Thinking Modernity, Post-Colonialism and Representation, London, Zed Books, 2002; Jane L. Parapart et al., eds, Re-Thinking Empowerment: Gender and Development in a Global/Local World, London, Routledge, 2002.

${ }_{13}$ Ray Whitehead, "Christ and Cultural Imperialism", in Lind and Brown, eds, Justice as Mission, p. 33.

${ }^{14}$ Following a feminist liberationist approach to theology and ethics, I frame my treatment of seeking church, public, and community right relations with specific interests: Where is engagement and accountability located? Whose concrete lives are represented? Is there a kaleidoscopic analysis of the causes of suffering and sources of hope? Are critical perspectives being developed? Do moral norms include relationality and interdependence, dignity and moral agency? Are private and public spheres connected? Does attention to justice embrace political economy as well as culture in a reflective and compassionate solidarity? See Elizabeth M. Bounds, Pamela K. Brubaker and Mary E. Hobgood, "Welfare Reform: A War against the Poor", in Welfare Policy: [feminist critiques], Elizabeth M. Bounds, Pamela K. Brubaker, and Mary E. Hobgood, eds, Cleveland, The Pilgrim Press, 1999, pp. 12-17.

15 For further analysis, see my essay "Seeking 'Right Relations': How Should Churches Respond to Aboriginal Voices?", The Journal of the Society for Christian Ethics, and, for example, Himani Bannerji, The Dark Side of the Nation: Essays on Multiculturalism, Nationalism, and Gender, Toronto, Canadian Scholars' Press, 2000; Enakshi Dua and Angela Roberston, Scratching the Surface: Canadian Anti-Racist Feminist Thought, Toronto, Women's Press, 1999; Judith Emberley, Thresholds of Difference: Feminist Critique, Native Women's Writings, and Postcolonial Critique, Toronto, University of Toronto Press, 1993; and M. Nourbese Philip, Frontiers: Essays and Writing on Racism and Culture, Stratford, Ontario, The Mercury Press, 1992. 
and how they shape and practice religion. In particular, we now see "that our best efforts may contain destructive distortions, or be harnessed for wrong ends." 16 The church es have received a wild-geese call to seek healing and justice as paths to transformative healing.

Dominant Canadian politics, identities and values are blind to the legacy of colonialism and imperialism that makes the cultural and, hence, ecclesial body of Canada unwell. In post-Christendom Canada, mainline churches and ecumenical bodies no longer dream of controlling society, but some have also refused to withdraw from the political realm or neglect their continuing sense of responsibility in the public arena. ${ }^{17}$ From roughly the turn of this century, it was the policy of the government of Canada to provide education to a portion of the Aboriginal peoples through "Indian Residential Schools". ${ }^{18}$ The schools were part of the colonial will to "civilize" abo riginal peoples, i.e., to enable them to become good citizens; to "inculcate a moral sense"; to christianize. The overall aim of missionary work was to enable Native peoples to assume the "privileges and responsibilities of Christian citizenship ... carrying demands for conformity to the mores of the majority." 19 While the missionary movement assumed Aboriginal peoples had a right to education and to hear the gospel, Christian churches also administered residential schools on behalf of the federal government. ${ }^{20}$ Aboriginal children were subjected to physical, spiritual, emotional and sexual abuse. Churches were complicit in what is now recognized as cultural abuse or genocide, in particular the eradication of traditional spirituality, which enabled the evidion of Aboriginal peoples from their land and control of them as targets for assimilation. The schools were one part of the overall assimilationist policy that continued explicitly into the 1950s, and that more recently has begun to be heard and publicly contested.

The United Church of Canada will serve as a case study of action and public statements that has fostered awareness and understanding as one dimension of seeking right relations between

\footnotetext{
${ }^{16}$ See Terry Anderson, "Lessons from the Residential Schools: Some Beginning Reflections", in Touchstone, May 1998, p. 26.

${ }_{7}^{7}$ See Roger Hutchinson, Prophets, Pastors; and Public Choices: Canadian Churches and the Mackenzie Valley Pipeline Debate, Waterloo, ON, Wilfred Laurier University Press for Canadian Corporation for Studies in Religion, Comparative Ethics Series, Volume 3, 1992, p. 92. For example, in the highly charged political debate over the Mackenzie Valley Pipeline, Roger Hutchinson proposes a dialogical ethical method and assesses the churches' contributions as developing public awareness, advocacy of native people's position, and pressing ethical and religious questions throughout that case.

${ }_{18}$ The term "residential school" only came into formal use in the 1920s. Before then such institutions were officially called "industrial" or "boarding" schools. See Why the Healing Fund? The United Church Response, p. 2.

${ }^{19} \mathrm{John}$ Webster Grant, In the Moon of Wintertime: Missionaries and the Indians of Canada in Encounter Since 1534, Toronto, University of Toronto Press, 1984, pp. 149, 185, cited in Jennifer Balls, Dangerous Memories: Cultural Genocide and the United Church of Canada (unpublished manuscript, St Andrew's College, Saskatoon, 1999), pp. 5-

${ }^{20}$ Most of the schools were managed for the government on contract by four churches: the Roman Catholic Church through some of its orders, the Anglican, Presbyterian and United. It is estimated that 100,000 children, i.e., about twenty percent of all status Indian students, attended the schools. For example, the United Church of Canada participated in the operation of a maximum of 13 residential schools from the 1920s until the last school closed in 1969.
} 
non-Aboriginal and Aboriginal peoples. ${ }^{21}$ In its brief to the Royal Commission on Aboriginal Peoples, the United Church has acknowledged:

The Residential Schools were premised on a racist understanding of the superiority of European civilization as it was being transplanted in North America, and the inferiority of Aboriginal societies. This racist premise was reinforced by the churches in their theology and their attitudes to Native spirituality. Contact between these two ways of living in the world led to a rapid and often brutal disintegration of the Aboriginal way of life. Combined with the relentless economic and social pressure of expansionist European society, the effects of the Residential Schools dealt an almost fatal blow to Aboriginal soci eties. ${ }^{22}$

In 1984, Alberta Billy, a First Nations' woman from Cape Mudge, British Columbia, issued an historic call to the United Church General Council's Executive (it's the church's highest decisionmaking body). "It is time you apologized to native peoples."23 On 15 August 1986 at the Sudbury G eneral Council, the church responded with an "Apology to Native Congregations" for having failed to respect the depth and richness of Aboriginal spirituality and vision, and for confusing the gospel of Jesus Christ with Western institutions and cultures:

Long before my people journeyed to this land, your people were here, and you received from your elders an understanding of creation, and of the mystery that surrounds us all that was deep and rich and to be treasured. We did not hear you when you shared your vision. In our zeal to tell you of the good news of Jesus Christ we were closed to the value of your spirituality. We confused Western ways and culture with the depth and breadth and length and height of the gospel of Christ. We imposed our civilization as a condition of accepting the gospel. We tried to make you like us and in so doing we helped to destroy the vision that made you what you were. As a result, you, and we, are poorer, and the image of the Creator in us is twisted, blurred and we are not what we are meant by God to be. We ask you to forgive us and to walk together with us in the spirit of Christ so that our peoples may be blessed and God's creation healed. ${ }^{24}$

${ }^{21}$ Selected documents from the United Church of Canada General Council, viz, 1986 Apology, Record of Proceedings, (1986), p. 85; 1997 Statement of Repentance, Record of Proceeding (1997), pp. 892-894; 1998 Apology, United Church of Canada press release, 27 October 1998; Why the Healing Fund? The United Church Response (1994); Justice and Reconciliation: The Legacy of Indian Residential Schools and the Journey Towards Reconciliation, Division of Mission in Canada, 2001. Official documents map a broad political and theological frame, and give an account of the state of relations; they can only suggest guidelines for ongoing participation. However, these ecclesially-sponsored social ethical teachings can help build awareness, communication and accountability in public spaces. There is no substitute for grassroots engagement.

22 "Brief to the Royal Commission on Aboriginal Peoples", 27 October 1993, p. 9, cited in Russ Daye, "An Unresolved Drama: Canada's United Church Seeks Reconciliation with Native Peoples", The Ecumenist, vol. 36, no. 2, April-May, 1999, p. 13.

${ }^{23}$ Stan McKay and Janet Silman, "A First Nations Movement in a Canadian Church", in The Reconciliation of Peoples: Challenge to the Churches, Gregory Baum and Harold Wells, eds, Maryknoll, NY, Orbis Books and Geneva, WCC Publications, 1997, pp. 173-4.

${ }^{24}$ United Church of Canada, Record of Proceedings, 1986, p. 85. 
The elders responded, "We must go back and talk to the people." They acknowledged but did not formally accept the apology; only an apology that is lived out could be real. Such accountability to right relations is the enduring horizon of any notion of mission.

This process of accountability holds the United Church responsible, as Stan McKay the first Aboriginal moderator asserts, for a history "for which it must repent". ${ }^{25}$ Reconciliation involves, therefore, not only listening to the suffering caused but also evidence that it has been heard, the wrong-doing has been acknowledged, and steps of repentance and redress are being taken. If apathy and denial are structured social sins, the 1986 apology marks a potential new beginning or "new partnership with First Nations communities." ${ }^{26}$ Aboriginal peoples in Canada are in theological terms the sinned against. The recent lawsuits filed by survivors of residential schools - the victims of the best intentions ${ }^{27}$ - have sharpened the understanding of the history for which the dominant churches must repent, i.e., the history of white racism and cultural genocide.

White congregations often resist or reject the idea that healing and justice include them too, or do not feel morally obliged or otherwise moved to participate in seeking right relations and a shared future. Sherene Razack analyses this blindness as "presumed innocence", and a determined non-involvement in social relations. ${ }^{28}$ In recent ecclesial attempts to listen to Aboriginal peoples and to build relationships across cultures and histories, the truth of domination and exclusion by white churches of Aboriginal peoples is being unmasked. The challenge for those of the dominant culture is to learn to understand and assess how religion and its symbols and practices are historically located and socially engaged.

\section{Conditions for reconciliation}

In an attempt to foster awareness and understanding, and to undertake healing and advocacy, a second project has just been released in the United Church. Justioe and Reconciliation: The L egacy of Indian Residential Schools and the Journey Towards Reconciliation (2001) is an educational pro gramme for non-Aboriginal congregations. As white liberal Protestantism struggles to cope with its disestablishment, and lives fragmented by globalizing trends, the temptation is to seek sta-

${ }^{25}$ Stan McKay uses the word genocide to account for the ongoing destruction of a people. "No one can explain to me the tremendous Indian population in the prisons, the large number of Native young people in juvenile detention centres or the overwhelming number of tiny babies being removed from Native homes and put in non-Native foster homes or adopted. This trading and exploitation of Native children is, for me, the final step in the genocidal process": in "The Church Has Some History for which it must Repent", in Stories of Survival: Conversations with Native North Americans, Kathleen and Remelt Hummelen, New York, Friendship Press, 1985, p. 64.

26 Why the Healing Fund?, p. 14.

${ }^{27}$ See Stan McKay and Janet Silman, "The Era of Residential Schools", in The First Nations: A Canadian Experience of Gospel-Culture, Geneva, WCC Publication, 1995, pp. 12-18.

${ }^{28}$ See Sherene H. Razack, Looking White People in the Eye: Gender, Race and Culture in Courtrooms and Classrooms, Toronto, University of Toronto Press, 1998, p. 170. Pamela Brubaker discusses avoidance and denial as coping strategies to deal with injustice and evil. See especially "What Does Faith Have to Do With Globalization?" in Globalization at What Price: Economic Change and Daily Life, Cleveland, OH, Pilgrim Press, 2001, pp. 63-81. 
bility by either retreating to privileged circles where salvation is identified as a purely spiritual experience unrelated to social context, or by (re)institutionalizing unjust relations by protecting churches from risking changes required to seek reconciliation. In the hopes of reconstructing and beginning new relationships out of the brokenness of dominance and subjugation, three normative practices of negotiating right relations are upheld:

i) Truth telling - to hear the stories of Aboriginal peoples in residential schools, to name racism, to see the gospel-culture connection, and to realize truth as plural;

ii) Lamentation and repentance - to experience grief and pain, recognize interconnectedness and solidarity, and move towards authentic repentance and transformation;

iii) Seeking the Spirit - only the Spirit of G od can pull us away from paralysis, and where, instead of acting, we need to wait on $\mathrm{G}$ od to learn how to restore balance. 29

These practices aim to open and shape a space welcoming a plurality of truth whereby "your truth does not deny my truth". 30 This assertion emphasizes and recovers the inseparability of truth and truthfulness - the fit among what is said and the persons who say it, and the context in which they say it. ${ }^{31}$ Truthfulness is the acting before and with others with self-reflexive and mutual accountability in specific contexts.

In relation to traditions and histories of mission, power dynamics have always carried weight in the creation and negotiation of mission. Fragmentary or ambiguous knowing assumes that power is uneven, contested, asymmetrical and necessary.

Power is simply the ability to control and to make things happen. In order to know whether power is good or bad, we need to know where it comes from, the intention with which it is used and the outcomes of its use.... We can see violence as a misuse or abuse of power. That should not make us deny power or refuse to use it.... We need power to right wrongs and to bring healing and reconciliation. Without the use of power, nothing good happens. There is a saying that evil triumphs when good people do nothing. 32

Some churches have lost touch with the very character of Jesus' life in its preoccupation with possessing itself of an authority over the so-called "uncivilized". Very often Christians have been anxious to establish superiority over others. Is this the kind of burden Jesus had in mind when

\footnotetext{
29Justice and Reconciliation, pp. 22ff; 38; 47ff. The final section entitled "Working in Solidarity: Toward Reconciliation" provides an overview of significant actions of national, regional and local church responses to injustices experienced by Aboriginal peoples, particularly in relation to the residential schools. Justice and Reconciliation: The Legacy of Indian Residential Schools and the Journey Towards Reconciliation, Division of Mission in Canada, 2001, is available from The United Church of Canada, 3250 Bloor Street West, Suite 400, Etobicoke, Ontario, Canada. M8X 2 Y4.

${ }^{30}$ This phrase is Stan McKay's, the first Aboriginal moderator of the United Church of Canada, 1992-1994.

31 On the inseparability of truth and truthfulness, see, for example, Margarita Pintos, "Truthfulness", in Dictionary of Feminist Theologies, eds, Letty M. Russell and J. Shannon Clarkson, Louisville, Westminster John Knox Press, 1996, p. 305.

32 Diane Mavunduse and Simon Oxley, Why Violence? Why Not Peace? Geneva, World Council of Churches, 2002, p. 10
} 
he said, "Take up your Cross and follow me"? Some Christians have been too preoccupied with who is correct, rather than with doing what Jesus did. Jesus went out and met people where they were. He punctured the pretensions of the pious and confronted the powerful with what they were really doing. Jesus placed more rigorous demands of faithful living upon the complacent. He aided those with mutilated self-respect, broken bodies, shattered lives and lost dignity to know that there is a power of healing which meets their needs.

As people respond to this challenge, some links are being made at the margins, for example, with Aboriginal communities, both within churches and beyond. Morally, the claim of the other is rendered possible in their being at the margins, and by the making of space for silenced and oppositional discourses in public. In this back and forthness, moral vision is enlarged. However, we must always live with bell hooks' (sic) clarification in mind: Solidarity is not the same as support. That is, to experience solidarity we must have a community of interest. 33 Beverly Harrison expands on the moral implications:

(We) need each other especially to survive and flourish as activists in the dominant churches. It is easy for us (in white middle class churches), women and men alike, to lose touch with the genuine scope of social oppression that is the existential condition of most human beings on this globe. Genuine struggle, the capacity to live with conflict and to resist the complacency of the dominant ethos, requires precisely those marks of transcendence bom of the acknowledgement of solidarity. O ur lives are worth struggling for, but only as part of this wider struggle. The capacity to know and name one's hurt, to recognize one's vulnerability, to bear suffering in order to work against unnecessary suffering is a blessing. This is our calling as Christians following the Way of Jesus. The temptation to permit Christianity to lapse back into an escapist spirituality, an accommodation to the power of privilege will be great if we do not learn to hold each other accountable to these realities ... Solidarity is continuous relationship, fidelity to relationship, and mutual accountability. 34

Reframing mission with this operative spirituality involves an understanding of the social consequences of lived theology. This leads to the need to acknowledge and transform assumptions, for example, that white Christians in a pluralist world are givers in relation to needy others and have a monopoly on God and truth and virtue. 35

\section{Reframing mission}

We will need new language and practices of mission if we are to learn to be in restored and right relationship. ${ }^{36}$ Jesus' way of salvation is an ethic of self- and neighbour love where, "By their

\footnotetext{
${ }^{33}$ See bell hooks (sic), Feminist Theory: From Margin to Center, Boston, South End Press, 1984, and Talking Back:

Thinking Feminist, Thinking Black, Boston, South End Press, 1989; also, Uma Narayan, "Working Together Across Difference: Some Considerations on Emotions and Political Practice", Hypatia 3 (Summer 1988), pp. 31-47. ${ }^{34}$ See Beverly Harrison, Making the Connections, pp. 233-234, 231.

${ }^{35} \mathrm{See}$, for example, Konrad Raiser, To Be the Church: Challenges and Hopes for a New Millennium, Geneva, WCC Publications, 1997.

${ }^{36}$ See the United Church of Canada General Council, Records of Proceedings, 1988, pp. $614 \mathrm{ff}$.
} 
fruits ye shall know them." This is Jesus' criterion of mission. Jesus teaches that, "The greatest commandment, the summary of the law and the prophets, is to love God with all one's heart, soul, strength, and mind and your neighbour as yourself" (Luke 10:27). A long-held missiology in keeping with this vision is "partnership", which is a model of empowerment that connects evangelism and the common good. I cite one definition from the United Church of Canada:

Partnership means becoming involved with others in God's mission for wholeness of life, especially with those who suffer from systems of injustice. Partnership brings people together in community for mutual empowerment through the sharing of gifts. We believe that movement towards a more just, participatory society will be fostered through the building of relationships of respect, and the shaing of resources, experiences and values among people. We acknowledge the need for mutual accountability, trust, honesty, forgiveness, and persistent love, which requires long-term commitments. ${ }^{37}$

Partnership missiology aims to develop long-term relationships of association and accompaniment, not the imposition of a dominant theology or analysis. Partnership missiology is an effort to remain in respectful and mutual relationship over the long hau1.38

The Jubilee is a biblical image that helps orient us to the hope that changes lives and hearts, that restores us to right relations. Jubilee communities are places where people gather to imagine God's promise of a day when all will be forgiven and land and liberty restored. Jubilee means asking, "D oes what we do increase the participation and power of those with little power?" And, as African theologian Mercy Amba Oduyoye observes, "Jubilee communities have always been communities of struggle that swim against the stream of what can easily be achieved." 39

Swimming against the stream requires constant negotiation. Some churches have learned a great deal from mission mistakes. Sometimes we are too enthusiastic about our own ideas - even those of partnership or justice or mutuality! Mission means carrying on G od's work of loving and seeking the justice that is its heart; it means participating in building up someone else's productive capacities; it means organizing against death with the power of God to heal and create and act in that power. No arena is excluded. We have learned that incarnation is about bodies, as well as minds and hearts. G ender justice has long been on the agenda of being church. In Canada churches are being called to take a stand in the heated conflict in national politics and churches about sexual orientation. The United Church of Canada, for example, officially advocates the gospel as inclusive and seeks a "normative diversity" where all persons, including gay, lesbian, bi-sexual and transgendered persons, can serve in ministry, and where, as our General Council recently agreed, samesex marriage is a constitutional right. 40

\footnotetext{
${ }^{37}$ Division of World Outreach, Gender Justice and Partnership Guidelines, Toronto, UCC, 1998, p. 6. 38 See, for example, UCC 32nd General Council Record of Proceedings, 1988, pp. 614ff.

39 Mercy Amba Oduyoye, "Re-Imagining the World: A Global Perspective", in Church and Society, Presbyterian Church (USA), May/June, 1994, p. 90.
}

${ }^{40}$ On "normative diversity", see Janet Jakobsen, Working Alliances, pp. 146-7. 
Thus, mission requires advocacy with those who are marginalized or excluded; it requires the creation of new relational spaces, and a continual checking of strategies and an assessment of the consequences of action with those who bear the burden. bell hooks insists that instead of meeting the "other" in the centre, as colonizer, those in the mainstream are called to meet the "other" in the margins:

This is an intervention. A message from that space in the margin that is a site of creativity and power, that inclusive power, that inclusive space where we recover ourselves, where we move in solidarity to erase the category of colonized/ colonizer. Marginality as site of resistance. Enter that space. Let us meet there. Enter that space. We greet you as liberators. ${ }^{41}$

Here the colonizers are not only implicated in, but are dependent upon the margins where voices of others, including ancestors and survivors, can jolt the colonizers into an awareness of what is really going on in the current political economic context, and help to critically locate complex selves in a world where many are being forced to relinquish valued ways of life.

The challenge for mission is to articulate and practice such normative diversity as an expression of faith, and as a participation in God's creative and healing power. Such an articulation and practice means including the scorned and rejected at our tables of eucharist and in our kitchens. It means reading the Bible as a resistant text and as resistant readers 42 who are self-engaged and otherregarding persons in relation. It means white people learning to be anti-racist. It means all people acknowledging that we are born of woman, and living to honour the gilt of life as inhabitants of one earth home. I take courage from Musa Dube's insistence on the possibility of a "liberating interdependence that recognizes and affirms the interconnectedness of relationships that affirm the dignity of all things and people."43 Accepting such a stance requires negotiating mission to associate with others in ways that do not presume intimacy with their experiences, that respect difference, and that will work to subvert yet more foreign or familiar impositions. ${ }^{44}$

\section{Conclusion}

Mission that takes seriously our own needs for healing and for solidarity with marginalized peoples does not aim to "civilize" others. Mission therefore requires mature dialogue in terms clarified by Emilie Townes as "self-critical inclusivity". If mission is to be about more than refusing to be dominated, it is also then about refusing to dominate. "The task constantly remains for us to evaluate goals and standards in light of the gospel understanding of justice. This justice is

\footnotetext{
41 bell hooks, Yearning, p. 153, cited by Gloria Albrecht, The Character of O ur Communities: Toward an Ethic of Liberationfor the Church, Nashville, Abingdon Press, 1995, p. 96.

421 am grateful to Jacques Matthey for this elaboration.

${ }^{43}$ Musa W. Dube, Postcolonial Feminist Interpretation of the Bible, Missouri, IL, Chalice Press, 2000, pp. 185-6.

${ }^{44}$ "I am indebted to Susan Gingell's discussion on how an engaged postcolonialism can work in Canada. See "The Absence of Seaming, Or How I Almost Despair of Dancing: How Postcolonial Are Canada's Literary Institutions and Critical Practices?" in Is Canada Postcolonial? Unsettling Canadian Literature, ed., Laura Moss, Waterloo, Wilfred Laurier University Press, 2003, pp. 107ff.
} 
dynamically revelatory - always within our grasp and just beyond it." 45 In relation to a countercolonizing norm of justice/ love for diverse discourses of mission, Sharon Welch's pragmatic criteria may help address the fear of diversity and ambiguity that arise in the midst of crisis and pluralism. Welch suggests three criteria for the truthfulness of analyses and strategies: "(i) their actual effect on the lives of people, (ii) their openness to further critique and hence modification, and (iii) their resiliency in the face both of critique and unintended consequences - positive and negative, unpredictable opportunities for further acts of responsibility and creativity ... Basically, we become ready to clean up after ourselves, to re evaluate actions, all with the style of humour and openness to failure." 46 Can we then hear in the wild-geese calls for right relations - not just concern but solidarity with and accountability to those made "other"?

Mission worth its salt, following rabbinic forthrightness, will therefore ask disturbing questions: "Whose mission is this?" "Which Christ do you follow?" "D oes this partnership temper our advocacy of justice in areas like sexual orientation or racial and gender justice?"47 "Who has power to name and decide?" "Who is included and who is excluded - in the name of Jesus Christ?" "How will this doctrine or policy affect the world's children?"

God's mission for the sake of the beloved world includes healing ourselves with the solidarity of others, and forging interdependent community based on justice/ love. Mission is a struggle to hope. 48 "Hope has two beautiful daughters. Their names are anger and courage: anger at the way things are, and courage to see that they do not remain that way." 49

To be authentically human is to centre one's life on the world G od so loves. It has always meant that, but today it is critical to do so. The creation God loves is sick unto death, and needs caretakers, lovers, gardeners, companions and partners who will work to preserve life rather than death, collective security rather than national security, rice in the mouth and a roof over the head rather than military and nuclear hardware. The kind of love that is need ed to make the vision a reality has tough sinews. It roots up and pulls down, builds and plants. It is full of tenderness. It bears all things, believes all things, hopes all things, endures all things. It wipes away tears from all eyes. ${ }^{50}$

As alert Christians attempt to disentangle churches from a concept of mission as "civilizing", can we reframe mission in terms of negotiating our place in "the family of things", to discover how to live in right relation, perched on God's ready promise of healing transformation?

\footnotetext{
${ }^{45}$ Emilie Townes, "Ethics as an Art of Doing the Work our Souls Must Have," in The Arts of Ministry: FeministWomanist Approaches, ed., Christie Cozad Neuger, Louisville, Westminster John Knox Press, 1996, p. 156.

${ }^{46}$ Sharon Welch, Sweet Dreams in America: Making Ethics and Spirituality Work, New York, Routledge, 1999, pp. 34, 123.

${ }^{47}$ See, for example, The United Church of Canada, Gender, Justice and Partnership Guidelines, 1998.

${ }^{48}$ See, for example, Melissa Chamberlain et al, Hope is the Struggle: A Community in Action, Toronto, United Church Publishing House, 1996.

${ }^{49}$ Augustine, cited by Dorothee Sölle in "Foreword", Bärbel von-Wartenberg Potter, We Will Not Hang Our Harps By the Willows: Engagement and Spirituality, Geneva, WCC, 1987.

${ }^{50}$ Lois Wilson, Turning the World Upside Down, Toronto, Doubleday, 1989, p. 252.
} 